\title{
Istota i główne modele power-sharing w kontekście wieloetniczności. Zarys problematyki
}

\begin{abstract}
Streszczenie: Artykuł traktuje w zarysie o istocie i głównych modelach power-sharing. Choć powersharing może być pojmowane w sposób bardzo szeroki, tematyka tego artykułu dotyczy jego wąskiego rozumienia. Odnosi się ono do fenomenu dzielenia się władzą państwową przez różne segmenty (np. grupy etniczne lub wspólnoty religijne) społeczeństw pluralnych (podzielonych, sfragmentaryzowanych), w tym zwłaszcza wieloetnicznych i/lub wieloreligijnych. Głównym celem artykułu jest wyjaśnienie treści power-sharing we wskazanym wąskim rozumieniu i wythumaczenie w zarysie jego głównych modeli (konfesjonalizm, model Lewisa, konsocjonalizm, centrypetalizm).
\end{abstract}

Słowa kluczowe: power-sharing, konfesjonalizm, model Lewisa, konsocjonalizm, centrypetalizm

$\mathbf{W}$ e współczesnej politologii coraz powszechniej stosowane jest pochodzące z języka angielskiego pojęcie power-sharing, które w piśmiennictwie nie-angielskojęzycznym występuje albo w pierwotnej wersji językowej w charakterze neologizmu, albo tłumaczone jest na języki narodowe ${ }^{1}$. W polskiej literaturze przedmiotu termin powersharing używany bywa często w oryginale, choć czasami jest tłumaczony jako „współrządzenie” (Słownik politologii, 2008, s. 669-670) lub „współdzielenie władzy” (Zdeb, 2014, s. 145).

Istnieje szerokie i wąskie rozumienie pojęcia power-sharing. To pierwsze ma charakter nazbyt ogólny, drugie zaś - skonkretyzowany i skonceptualizowany, i odnosi się w naukach politycznych do fenomenu systemowego dzielenia się władzą państwową przez różne segmenty (np. grupy etniczne lub wspólnoty religijne) społeczeństw pluralnych (podzielonych, sfragmentaryzowanych), w tym zwłaszcza wieloetnicznych i/lub wieloreligijnych. Pojęciu power-sharing w drugim znaczeniu czasami towarzyszy przymiotnik. W konsekwencji w użyciu są takie terminy jak np. etniczne power-sharing (ethnic lub interethnic power-sharing, Horowitz, 2014, s. 5), religijne power-sharing (religious power-sharing, O’Leary, 2005, s. 33) oraz etniczno-religijne power-sharing (ethno-religious power-sharing, Berman, 2009, s. 52).

Głównym celem tego artykułu jest wyjaśnienie istoty power-sharing w wąskim rozumieniu i wytłumaczenie w zarysie jego głównych modeli w warunkach wieloetniczności, co jednak, dla klarowności i kompletności, zostało poprzedzone objaśnieniem szerokiego znaczenia przedmiotowego pojęcia.

${ }^{1}$ Np. w j. francuskim - partage du pouvoir, w j. niemieckim - (die) Machtteilung, a w j. hiszpańskim - reparto de poder (Collins English Dictionary). 


\section{Power-sharing w szerokim rozumieniu}

Słowniki językowe definiują power-sharing ${ }^{2}$ lakonicznie. I tak np. według Macmillan Dictionary, power-sharing to „porozumienie, w ramach którego dwie grupy dzielą się odpowiedzialnością za kierowanie rządem". W tej symplicystycznej definicji dziwi zwłaszcza fakt, że wspomnianą odpowiedzialnością mogą się dzielić jedynie dwie grupy. Trochę lepszą propozycję ma The New Oxford Dictionary of English (2001, s. 1455), który thumaczy przedmiotowy termin jako ,przyjętą pomiędzy partiami politycznymi bądź w ramach koalicji politykę dzielenia się odpowiedzialnością za podejmowanie decyzji oraz działania polityczne". Merytorycznie nieco szerszą definicję power-sharing można zaś znaleźć w Collins English Dictionary, według którego pojęcie to oznacza takie „ustalenia polityczne, dzięki którym przeciwstawne sobie w społeczeństwie grupy uczestniczą w rządzeniu".

Praktyka wskazuje jednak, że pojęcie power-sharing w zależności od kontekstu może mieć odmienne, choć zarazem zbliżone znaczenia i odnosić się do rozmaitych podmiotów oraz wymiarów dzielenia się władzą (Wolff, 2010, s. 535-556). Za podstawowy rodzaj power-sharing należy uznać klasyczną monteskiuszowską koncepcję trójpodziału władzy pomiędzy legislaturę, egzekutywę i sądownictwo. W wymiarze horyzontalnym dzielenie się władzą może również następować między różnymi partiami politycznymi (w ramach koalicji rządowych), ale także między partiami politycznymi a innymi podmiotami (np. związkami zawodowymi i szerzej - różnymi organizacjami i ruchami społecznymi), jak również między mężczyznami a kobietami (perspektywa studiów gender) $)^{3}$.

Rodzajem szeroko rozumianego power-sharing jest też dzielenie się przez elity polityczne posiadaną władzą z obywatelami. $\mathrm{Z}$ takim zjawiskiem mamy do czynienia zwłaszcza w warunkach demokracji partycypacyjnej (uczestniczącej) lub deliberacyjnej (deliberatywnej). Oba rodzaje demokracji w nieco odmienny sposób dopuszczają niepolityków do procesu podejmowania decyzji politycznych. Pierwsza z nich funkcjonuje na poziomie samorządów lokalnych, a jej najczęściej stosowaną instytucją jest budżet partycypacyjny (della Porta, 2013, s. 36-59). Druga zaś, promując debaty (w tym eksperckie) jako drogę do podejmowania lepszych jakościowo i posiadających szerszą legitymację społeczną decyzji politycznych, może istnieć na różnych poziomach władzy, choć nadal jest głównie konceptem teoretycznym (della Porta, 2013, s. 60-84).

Z kolei za rodzaj wertykalnego power-sharing uważa się rozmaite rozwiązania struktury terytorialno-administracyjnej państwa, w tym decentralizację i federalizację. I tak np. Daniel J. Elazar (1995, s. 474-475), omawiając znaczenie pojęcia federalizmu, zauważa, że może być ono rozumiane jako ,ustalone w konstytucji dzielenie się władzą poprzez system, który łączy w sobie samozarządzanie częściami państwa z udziałem w rządzeniu jego całością".

Jak wskazują przytoczone przykłady, w szerokim ujęciu pojęcie power-sharing może być bardzo pojemne. Pojęcie to dotyczy wówczas udziału w jakimś rodzaju władzy i na jakimś jej poziomie więcej niż jednego podmiotu, grupowego lub instytucjonalnego.

${ }^{2} \mathrm{~W}$ słownikach i literaturze przedmiotu występuje również forma zapisu tego pojęcia pozbawiona łącznika, power sharing.

${ }_{3}$ Zob. szerzej np. Keating (1998), DeWitt (2000), Kittilson i Schwindt-Bayer (2010). 


\section{Power-sharing jako termin skonkretyzowany}

Mimo, że pojęcie power-sharing funkcjonuje w języku angielskim jako sui generis termin-worek, w politologii występuje również jego dookreślone rozumienie odnoszące się do uzgodnień powstałych i ugruntowanych w relacjach między elitami politycznymi reprezentującymi odmienne części społeczeństw pluralnych, tj. składających się z różnych grup społecznych, zwłaszcza o charakterze etnicznym, narodowym, religijnym czy wyznaniowym, które w literaturze przedmiotu określane są często mianem segmentów lub subkultur.

Pojęcie power-sharing doczekało się konceptualizacji właśnie w odniesieniu do zjawiska dzielenia się władzą między różnymi segmentami społeczeństw pluralnych. W tym przypadku nastąpiło zatem przejście od stadium wyobrażenia, czy też poglądów dotyczących jego treści, to znaczy od pojęcia przed-teoretycznego (ang. notion) na poziom pojęcia teoretyzowanego (ang. concept), a więc i skonkretyzowanego. W konsekwencji przedmiotowy termin może być w kontekście społeczeństw pluralnych pojmowany w sposób jednoznaczny, co nie wyklucza istnienia różnych modeli power-sharing.

$\mathrm{Z}$ punktu widzenia tematu tego artykułu najistotniejsze jest wskazanie na znaczenie power-sharing w specyficznych warunkach społeczeństw wieloetnicznych. I tak np. Rick Wilford (2003, s. 434) zauważa, że power-sharing w sytuacji istnienia podziałów i rywalizacji etnicznej wiąże się z włączaniem w proces rządzenia zwłaszcza przywódców oraz partii politycznych reprezentujących odmienne segmenty etniczne. Jak konstatuje Geraint Parry (1995, s. 1283), w społeczeństwach, w których wprowadzono power-sharing, ,sposób politycznego działania wynika z ustaleń wynegocjowanych w gronie liderów segmentów w ramach procesu określanego jako akomodacja elit”, która polega na wzajemnym przystosowywaniu się i budowaniu kompromisów w gronie członków elit politycznych reprezentujących interesy odmiennych segmentów. Podobne opinie wyraża Timothy D. Sisk (1996, s. 4), gdy stwierdza, że power-sharing w warunkach wieloetniczności propaguje tworzenie rządów przeważającej części, ,jeśli nie wszystkich głównych i zorganizowanych politycznie grup etnicznych społeczeństwa". Jego zdaniem, power-sharing powinno być inkluzywne wobec tych reprezentantów wszystkich grup, którzy posiadają ich szeroką legitymację. Podstawą procesu decyzyjnego w ramach power-sharing musi zaś być kooperacja elit, która wychodzi ponad interesy grupowe.

W fachowym piśmiennictwie politologicznym power-sharing najczęściej przedstawiane jest jako rodzaj systemu politycznego (Sisk, 1996, s. 4). Wiąże się to z faktem, że ogół jego cech wykracza poza takie pojęcia jak „system rządów”, „forma rządów” czy „reżim polityczny” i obejmuje w ramach danej wspólnoty politycznej, obok charakterystycznych dla niej struktur, instytucji i organizacji, specyficzne: świadomość, kulturę, stosunki, wartości i normy. Gdy jednak te ostatnie cechy nie zostaną jeszcze wykształcone, power-sharing wprowadzane mechanicznie (np. w wyniku osiagniętego ad hoc porozumienia pokojowego wieńczącego konflikt między wrogo nastawionymi do siebie segmentami), może być po prostu uznawane za zbiór rozwiązań strukturalnych (np. decentralizacja), instytucjonalnych (np. rządy wielkiej koalicji) i organizacyjnych (np. partie etniczne) stanowiących istotną część danego systemu politycznego. Najczęściej jednak formalne rozwiązania strukturalne, instytucjonalne i organizacyjne, jako ukoronowanie długotrwałych uzgodnień między elitami politycznymi poszczególnych seg- 
mentów, stanowią po prostu rezultat rozwoju konsensualnej kultury politycznej. Świadomość potrzeby osiaggnięcia konsensusu często wzrasta w sytuacji przedłużania się jakiegoś konfliktu (Noel, 2005, s. IX). Konflikty w społeczeństwach pluralnych, w tym wieloetnicznych, uzmysławiają politykom, że stosunki między segmentami muszą opierać się na normach i wartościach szerszych od partykularnych, a konkretnie takich, które godzą różne interesy.

Warto teraz zwrócić uwagę na celowość implementacji i funkcjonowania power-sharing. W piśmiennictwie wskazuje się, że podstawową korzyścią z zastosowania tego systemu, w tym zwłaszcza całości lub jakichś elementów jego głównych modeli, jest z pewnością budowanie w społeczeństwach pluralnych stabilności politycznej. W przypadku takich społeczeństw zagrożeniem dla stabilności bardzo często są zaś konflikty w relacjach między segmentami. Dobrze zaprojektowane i przestrzegane, zwłaszcza przez największe i najsilniejsze segmenty rozwiązania power-sharing, mają w zamierzeniu wychodzić naprzeciw istniejącym różnicom i pomagać godzić sprzeczne interesy, a w konsekwencji ograniczać konflikty etniczne, religijne i tzw. communal conflicts (na poziomie wspólnot lokalnych, niejednokrotnie podzielonych według linii etnicznych i/lub religijnych). Dzięki dopuszczeniu do procesów decyzyjnych elit politycznych różnych segmentów, power-sharing powoduje zarazem ograniczanie koncentracji władzy przez większość i w rezultacie zmniejsza arbitralność władzy.

Power-sharing może zawierać rozwiązania polityczne, które mają charakter formalny, zinstytucjonalizowany, ale także, choć ma to miejsce rzadziej, o charakterze nieformalnym. System ten może towarzyszyć zarówno reżimowi demokratycznemu, jak $i$ autorytaryzmowi, zwłaszcza rywalizacyjnemu.

Power-sharing może dotyczyć zarówno stanu rzeczywistego, jak i stanowić teorię empiryczną bądź normatywną, które proponują rozwiązania instytucjonalne dla społeczeństw pluralnych (O’Leary, 2005, s. 3-36).

$\mathrm{W}$ rozmaitych encyklopediach i słownikach z zakresu nauk społecznych power-sharing bywa czasami utożsamiane błędnie, na zasadzie pars pro toto, $\mathrm{z}$ jednym ze swoich rodzajów - konsocjonalizmem (ang. consociationalism), który jednak w szczegółowej literaturze przedmiotu uznawany jest po prostu za najbardziej znany model power-sharing.

\section{Główne modele power-sharing}

\section{Libański konfesjonalizm}

W piśmiennictwie wskazuje się model wypracowany w Libanie w 1943 r. jako najwcześniejszy przykład sformalizowanego systemu power-sharing. Libańskie społeczeństwo składa się z odmiennych segmentów, zwłaszcza religijnych i wyznaniowych, a w mniejszym stopniu również etnicznych, choć te nie zawsze łatwo wyodrębnić. Dwa główne segmenty religijne - muzułmanie i chrześcijanie dzielą się na sub-segmenty: muzułmanie - na sunnitów i szyitów, a chrześcijanie - na maronitów, wyznawców prawosławia i grekokatolików. Podział ten dodatkowo komplikuje obecność druzów, których wiara łączy podstawy islamu z elementami chrześcijaństwa i innych wierzeń. 
Najważniejsze siły polityczne określiły podstawową treść libańskiego systemu power-sharing w podpisanym w 1943 r. tzw. Pakcie Narodowym. W jego ramach ustaliły zwłaszcza podział między segmenty wyznaniowe (i zarazem religijne, a po części etniczne) najważniejszych stanowisk politycznych w państwie. I tak urząd prezydenta przypadł maronitom, teka premiera - sunnitom, stanowisko marszałka jednoizbowego parlamentu - szyitom, zaś stanowisko wicemarszałka parlamentu - prawosławnym Grekom. Donald L. Horowitz uznaje uzgodnienia Paktu Narodowego za konstytuujące w Libanie instytucję tzw. miejsc zastrzeżonych (ang. reserved seats), tj. miejsc, na które mogą kandydować lub zostać wybrani jedynie członkowie konkretnego segmentu. Libański power-sharing dotyczy również rozdziału między członków poszczególnych segmentów konkretnej liczby mandatów parlamentarnych, stanowisk w służbie cywilnej oraz tek ministerialnych (Lijphart, 1980, s. 147-150).

Postanowienia Paktu Narodowego de facto nie obowiązywały w okresie wojny domowej w Libanie w latach 1975-1990. Co prawda, na załamanie porozumienia i wybuch konfliktu wpłynęły w pewnym stopniu uwarunkowania międzynarodowe, lecz istotniejszym problemem było to, że w okresie 1943-1975 w Libanie nastapiły znaczące zmiany demograficzne powodujące przeobrażenia w proporcji udziału poszczególnych segmentów wyznaniowych w populacji państwa. Dla elit politycznych części segmentów zmiany te nie były wystarczającym powodem, by przekształcać raz wynegocjowane ustalenia w zakresie sztywnych proporcji podziału między segmentami urzędów i stanowisk publicznych. Zachowawczość ta wpłynęła destrukcyjnie na istniejący między segmentami kompromis i przyczyniła się do zaognienia międzysegmentowych relacji. Horowitz (2014, s. 11-14) określa zaistniały fenomen mianem „problemu immobilizmu”.

Krwawa wojna domowa spowodowała jednak zmianę myślenia części elit politycznych i doprowadziła do istotnych przekształceń niektórych postanowień Paktu Narodowego. W 1989 r. główni aktorzy libańskiej sceny politycznej podpisali tzw. Porozumienie z Taif, którego celem było zakończenie wojny domowej. Umowa ta, zwana również Kartą Zgody Narodowej, wprowadziła rozmaite zmiany dotyczące rozdziału między części społeczeństwa pluralnego liczby mandatów parlamentarnych, stanowisk w służbie cywilnej i funkcji ministerialnych. Zarazem jednak potwierdziła wcześniejszy system alokacji między główne segmenty wyznaniowe najważniejszych stanowisk politycznych w Libanie.

Mieszkańcy Libanu mają rozmaite pochodzenie etniczne oraz przynależność religijną i wyznaniowa, ale tworzą jedną wspólnotę językową. Podział władzy nastapił zaś w Libanie między odmiennymi wspólnotami wyznaniowymi. W konsekwencji libański power-sharing określany jest w piśmiennictwie (Harb, 2006) mianem konfesjonalizmu (ang. confessionalism). Modelu tego nie sposób zatem uznać za charakterystyczny dla społeczeństw wieloetnicznych, jakie istnieją np. w państwach Afryki Subsaharyjskiej lub w różnych częściach Azji.

\section{Model Lewisa}

Pierwszy rozwinięty teoretyczny wzorzec power-sharing adresowany dla typowych społeczeństw wieloetnicznych (zwłaszcza afrykańskich) zaproponował, w latach 60. XX w., 
W. Arthur Lewis ${ }^{4}$ (Lijphart, 1995, s. 858). Lewis, który spędził część życia w państwach Afryki Zachodniej był świadom tego, że partie polityczne w warunkach wieloetniczności bardzo często powstają w oparciu o istniejące podziały etniczne, a w swych działaniach w mniej lub bardziej jawny sposób bronią interesów reprezentowanych przez nie grup etnicznych. Nie uważał tego zjawiska za niedemokratyczne. Jako przeciwnik autorytaryzmu, Lewis twierdził, że demokracja jest właściwym reżimem politycznym dla państw wieloetnicznych, lecz nie jej wzorzec większościowy. Polityka w klasycznej demokracji większościowej, jak pisał, ,jest tym, co matematycy nazywają grą o sumie zerowej: to, co ja zdobywam, ty tracisz" i dodawał, że funkcjonowanie takiego wzorca demokracji w warunkach wieloetniczności jest „zgubne dla szansy zbudowania państwa, w którym różne ludy mogą wspólnie żyć w harmonii” (Lewis, 1965b, s. 65-66). W konsekwencji zaproponował taką systemową korektę reżimu demokratycznego, która w założeniu odpowiadałaby potrzebie pogodzenia interesów różnych segmentów etnicznych. Korekta ta miała charakter rozwiązań power-sharing i weszła do teorii nauk politycznych jako model Lewisa (Lijphart, 1980, s. 143).

Model Lewisa składa się z trzech rozwiązań politycznych, które - w jego opinii - powinny istnieć jednocześnie. Są to: system proporcjonalny w wyborach przedstawicieli do parlamentu; rząd koalicyjny - tworzony zwłaszcza przez największe partie polityczne na przykład w taki sposób, by liczba tek ministerialnych była przyznawana partiom proporcjonalnie do ich wyniku wyborczego - mający w praktyce formę szerokiej koalicji międzyetnicznej; a także federalizm lub inny typ regionalnej decentralizacji jako przejaw autonomii segmentów etnicznych (Lewis, 1965b, s. 50-51; Trzciński, 2013, s. 33-47).

W opinii Lewisa, wieloetniczny charakter społeczeństwa powinien determinować wprowadzenie proporcjonalnego systemu wyborczego, który pozwala na uzyskanie bardziej reprezentatywnego składu parlamentu niż ma to miejsce w przypadku systemu większościowego (Lewis, 1965a, s. 11-12). Lewis uważał też, że zaakceptowanie przez grupy etniczne danego systemu politycznego wymaga tego, by posiadały one adekwatną do swego udziału w populacji całego państwa reprezentację w parlamencie. Lewis był zwolennikiem ordynacji pojedynczego głosu przechodniego (PGP), która kreuje proporcjonalność poprzez wskazanie przez wyborcę preferencji wobec wszystkich kandydatów w wielomandatowym okręgu i pozwala na ich uszeregowanie od najbardziej do najmniej pożądanego.

Lewis twierdził, że główną korzyścią z zastosowania w państwach wieloetnicznych ordynacji PGP byłoby wyłanianie reprezentacji proporcjonalnej składającej się z polityków o umiarkowanych poglądach, którzy powinni skłaniać się ku konstytuowaniu rządu szerokiej koalicji. Jak przewidywał, krytycy tego poglądu mogą dowodzić, że zastosowanie ordynacji PGP przyniosłoby efekt w postaci wielu małych partii politycznych w parlamencie, co nie sprzyjałoby nawiązywaniu i utrzymywaniu trwałej współpracy. Na podstawie obserwacji sceny politycznej w Ghanie i Nigerii, Lewis uważał jednak, że

${ }^{4}$ W. Arthur Lewis (1915-1991) - pochodzący z Saint Lucia brytyjski ekonomista i teoretyk polityki; wykładowca m.in. Uniwersytetu w Manchesterze oraz Princeton; laureat nagrody Nobla w dziedzinie ekonomii w 1979 r.; doradca m.in. Kwame Nkrumaha, przywódcy Ghany w latach 1957-1966, a także rządów nigeryjskich; zwolennik rozwiązań politycznych, które gwarantują szeroką partycypację obywateli w życiu politycznym oraz zapewniają daleko posuniętą decentralizację władzy. Zob. szerzej Sir Arthur Lewis - Biographical (2014). 
„dwie, trzy bądź cztery istotne partie to najbardziej prawdopodobny wynik” np. w Afryce Zachodniej (Lewis, 1965b, s. 81). Wiele państw tego regionu, choć zwykle charakteryzuje się złożonym składem etnicznym, zamieszkiwanych jest zaledwie przez kilka liczebnie dominujących w całej populacji grup etnicznych. Aby jednak uniknąć obstrukcji przy powstawaniu rządu koalicyjnego, Lewis postulował, by największe partie polityczne były konstytucyjnie zobligowane do jego tworzenia. Ponadto był przekonany, że udział w rządzie koalicyjnym byłby dla reprezentowanych przez partie polityczne grup etnicznych po prostu opłacalny ekonomicznie.

Zdaniem Lewisa, trzeci element modelu - decentralizacja, która zwłaszcza w przypadku dużych państw mogłaby mieć charakter federalizacji, zapobiegałaby nadcentralizacji władzy. Jak zauważał, monopolizacja procesu podejmowania decyzji w rękach władzy centralnej jest szkodliwa dla mieszkańców regionów m.in. dlatego, że zwykle niedostatecznie zna ona regionalne i lokalne problemy oraz potrzeby. W konsekwencji decentralizacja polityczna musiałaby również oznaczać decentralizację ekonomiczną dotyczącą m.in. poboru niektórych podatków.

Model power-sharing autorstwa Lewisa, skupiający się głównie na kwestiach strukturalnych, instytucjonalnych i organizacyjnych nie został implementowany w żadnym z państw afrykańskich. Jego istotna wartość polega jednak na tym, że stał się on, obok libańskiego konfesjonalizmu, podstawą dla rozwoju konsocjonalizmu, zwłaszcza w warunkach wieloetniczności.

\section{Model konsocjonalny (konsocjonalizm)}

Model konsocjonalny power-sharing został skonceptualizowany i nadal jest rozwijany przez Arenda Lijpharta 5 (1968, 1980, 2008) oraz jego uczniów na podstawie doświadczeń różnych państw lub ich części (począwszy od lat 40. XX w.), w tym zwłaszcza: Austrii, Belgii, Bośni i Hercegowiny, Cypru, Etiopii, Holandii, Indii, Irlandii Północnej, Kolumbii, Macedonii, Malezji, Republiki Południowej Afryki i Szwajcarii (Saurugger, 2016; Lijphart, 2008, s. 44; O’Leary, 2005, s. 3$)^{6}$.

Choć Lijphart (2008, s. 29) podkreśla, że za główną cechę charakterystyczną konsocjonalizmu powinno się uznawać „wspólny, celowy wysiłek elit na rzecz stabilizacji systemu", a nie same rozwiązania formalne, to zarazem uważa, że stabilność polityczna i ograniczanie międzysegmentowych konfliktów są możliwe w społeczeństwach pluralnych, również w głęboko podzielonych zwłaszcza wówczas, gdy rozwinęły one cztery szczególne elementy konsocjonalne. Są to: rządy wielkiej koalicji, w skład których wchodzą reprezentanci wszystkich głównych segmentów lingwistycznych (etnicznych/ narodowych) i religijnych (i/lub wyznaniowych), którzy mogą należeć do partii repre-

${ }^{5}$ Arend Lijphart (ur. 1936) - holenderski i amerykański politolog, emerytowany profesor Uniwersytetu Kalifornii w San Diego; główny teoretyk power-sharing i autor wielu prac w tej materii; badacz systemów wyborczych i rozwiązań konsensualnych w systemach politycznych zwłaszcza społeczeństw pluralnych; propagator wprowadzania demokracji i instytucji konsocjonalizmu w tego typu społeczeństwach.

${ }^{6}$ W każdym ze wskazanych przypadków stosowano w przeszłości lub stosuje się obecnie przynajmniej część rozwiązań mieszczących się w ramach modelu konsocjonalnego. 
zentujących interesy konkretnych segmentów (np. do partii etnicznych); autonomia kulturowa dla tych segmentów, która może przyjąć różne formy (a jeśli segmenty zamieszkują zwarty obszar, wówczas autonomia może mieć również charakter terytorialny); proporcjonalność w reprezentacji politycznej oraz przy mianowaniu pracowników służby cywilnej; a także prawo weta dla (segmentów) mniejszości w odniesieniu do kwestii związanych z ich zasadniczymi prawami oraz autonomia, czasami przybierające postać wymogu uzyskania kwalifikowanej większości dla niektórych rodzajów zmian w prawie (Lijphart, 2008, s. 42; Trzciński, 2013, s. 47-57). Lijphart dzieli wskazane rozwiązania na podstawowe oraz drugorzędne, gdyż, jak zauważa, doświadczenie funkcjonowania elementów konsocjonalnych w różnych państwach uczy, że ,wielka koalicja i autonomia mają znaczenie kluczowe, podczas gdy pozostałe dwa są nieco mniej istotne" (2008, s. 4).

Obok rozwiązań formalnych Lijphart przywiązuje dużą wagę do niezwykle istotnej dla stworzenia i powodzenia systemu power-sharing kwestii zachowań elit oraz reprezentowanych przez nie segmentów rozumianych jako masy. Jak wskazuje, w konsocjonalizmie „tendencje odśrodkowe, właściwe dla społeczeństwa pluralnego” powinny być neutralizowane przez takie „postawy i zachowania przywódców różnych segmentów społeczeństwa, które charakteryzują się współpracą" (Lijphart, 1980, s. 1). Współpraca między elitami powinna zaś stymulować rozwój lepszych relacji na poziomie mas, tj. między członkami odmiennych segmentów.

Ważna rola rozwijanej przez Lijpharta i jego kontynuatorów teorii konsocjonalnej polega na tym, że próbuje ona oszacować szanse ustanowienia oraz utrzymania w społeczeństwach pluralnych konsocjonalnego modelu power-sharing. Wieloletnie badania różnych przypadków empirycznych doprowadziły Lijpharta (2008, s. 51-52) do wyodrębnienia dziewięciu czynników kontekstowych, które mogą wspierać bądź utrudniać konsocjonalny power-sharing. W opinii Lijpharta dwa z nich odgrywają podstawową rolę. Są to: brak lub obecność segmentu dominującego, czyli stałej większości, która zwykle preferuje rozwiązania charakterystyczne dla autorytaryzmu (monopol władzy) lub demokracji większościowej (współzawodnictwo, a niekiedy dominację); oraz brak lub obecność rozległych różnic ekonomicznych między poszczególnymi segmentami, które z reguły utrudniają porozumienie polityczne. Pozostałe czynniki kontekstowe to: mała lub duża liczba segmentów (im jest ich więcej, tym trudniejsze i bardziej złożone jest osiaganie rozwiązań konsensualnych); wielkość segmentów (gdy jest podobna, w ich wzajemnych relacjach łatwiej o równowagę sił i odwrotnie); wielkość populacji państwa (podejmowanie decyzji jest mniej złożone, gdy jest ona relatywnie mała i odwrotnie); brak lub istnienie jakiegoś zagrożenia zewnętrznego (drugi przypadek może wpływać na rozwijanie narodowej jedności); poziom rozwoju nadrzędnej lojalności (im wyższy, tym mniejsza jest siła lojalności partykularnych i odwrotnie); poziom geograficznej spójności segmentów (im większy, tym bardziej możliwe jest ustanowienie systemu federalnego sprzyjającego autonomii grupowej); a także brak lub istnienie tradycji budowania kompromisów (oczywiście w drugim przypadku power-sharing jest łatwiejsze).

Lijphart zdaje sobie sprawę z tego, że konsocjonalizm jako pełny model teoretyczny jest propozycją o charakterze idealnym, trudną do całościowej implementacji, zwłaszcza dlatego, że dynamika ewolucji systemów politycznych w społeczeństwach pluralnych jest zwykle powolna. Uważa jednak, że rozwiązania polityczne wychodzące naprzeciw 
potrzebom odmiennych segmentów takich społeczeństw mogą w praktyce przybierać rozmaite formy czy też warianty rozwiązań modelowych konsocjonalizmu. W konsekwencji, obok kompleksowego modelu konsocjonalnego wyróżnia także pojedyncze elementy konsocjonalne w systemach politycznych i, jak sugeruje, systemy polityczne nie muszą posiadać ogółu elementów konsocjonalizmu, aby móc je określać mianem konsocjonalnych.

\section{Model centrypetalny (centrypetalizm)}

Centrypetalizm (ang. centripetalism), w przeciwieństwie do konsocjonalizmu, nie ma jednego głównego teoretyka, a wiedza na jego temat bazuje przede wszystkim na rozmaitych analizach praktycznych doświadczeń Nigerii (od 1979 r.) i Indonezji (od 1999 r.), jedynych państw, w których system ten funkcjonuje. Centrypetalizm można zdefiniować jako specyficzny system polityczny państw wieloetnicznych o prezydenckim systemie rządów, który dopuszcza do udziału we władzy reprezentantów elit politycznych różnych grup etnicznych, stymulując ich do pojednania, współpracy i integracji politycznej w poprzek podziałów etnicznych (Trzciński, 2015, s. 184-190).

Zwolennicy rozwiązań centrypetalnych są przekonani, że elity, usatysfakcjonowane współudziałem w rządzeniu i możliwością obrony interesów swoich segmentów, powinny działać łagodząco na zachowania ich członków w relacjach z odmiennymi segmentami. Innymi słowy, akomodacja na poziomie elit powinna się z czasem przełożyć na stosunki na poziomie mas. I to w większym stopniu niż w przypadku konsocjonalizmu. Bowiem centrypetalizm z założenia promuje te poglądy i działania polityczne, szczególnie w kwestiach dotyczących interesów poszczególnych segmentów, które mają charakter umiarkowany, co ma umożliwiać trwały rozwój pokojowej egzystencji społeczeństw pluralnych. Co więcej, jak wskazuje Benjamin Reilly (2011, s. 290), twórcy i propagatorzy tego systemu poprzez wdrażanie szczególnych rozwiązań strukturalnych, instytucjonalnych i organizacyjnych, służących popularyzacji i uzyskiwaniu w polityce zachowań wychodzących ponad partykularne interesy etniczne, dążą do depolityzacji etniczności.

Osiągnięciu wskazanych celów służyć powinno przede wszystkim równoczesne stosowanie kilku rozwiązań formalnych odnoszących się zwłaszcza do: rodzaju struktury terytorialnej, reguł wyboru prezydenta oraz zasad działalności partii politycznych (Trzciński, 2015, s. 196-209). Jądro centrypetalizmu tworzą trzy konkretne elementy. Po pierwsze, jest to struktura terytorialna, w ramach której duże grupy etniczne są ,,rozbijane" w taki sposób, by ich członkowie zamieszkiwali w odrębnych, najlepiej wieloetnicznych jednostkach terytorialno-administracyjnych. To ma powodować, by elity polityczne wewnątrz tej samej dużej grupy, reprezentując różne regiony, konkurowały ze sobą na przykład o przydział środków z budżetu centralnego. Po drugie, jest to konstytucyjny wymóg uzyskania przez polityków kandydujących w wyborach prezydenckich terytorialnego rozłożenia głosów (zdobycia poparcia elektoratu w dużej liczbie regionów danego państwa $)^{7}$, sprostanie któremu jest niezbędne dla objęcia urzędu prezydenckiego.

${ }^{7} \mathrm{Na}$ przykład zdobycia co najmniej $25 \%$ głosów oddanych w każdym z co najmniej $2 / 3$ wszystkich stanów, jak ma to miejsce w Nigerii, lub minimum $20 \%$ głosów w ponad $50 \%$ prowincji, jak jest to w przypadku Indonezji. 
Po trzecie, są to ponadregionalne i międzyetniczne partie polityczne, prawnie zmuszone do tworzenia etnicznie heterogenicznych list kandydatów m.in. w wyborach parlamentarnych.

W literaturze przedmiotu wymieniany jest również czwarty element centrypetalizmu - stosowanie w wyborach do parlamentu, szczególnie zaś izby niższej, tzw. głosowania preferencyjnego $\mathrm{w}$ formie proporcjonalnego ( $\mathrm{w}$ okręgach wielomandatowych) systemu ordynacji PGP lub w postaci większościowego (w okręgach jednomandatowych) systemu głosu alternatywnego (Horowitz, 2003, s. 122-125). W głosowaniu preferencyjnym, dzięki stworzeniu rankingu kandydatów, wyborcy wyrażają swoje preferencje odnośnie kandydatów różnych partii. Zadaniem takiego typu głosowania w systemie centrypetalnym byłoby ograniczenie możliwości zdobycia mandatów parlamentarnych przez tych polityków, którzy nie zachowują powściagliwości w sprawach kluczowych dla podtrzymywania dobrych stosunków między poszczególnymi segmentami etnicznymi. Głosowania preferencyjnego nie wprowadzono jednak ani w Nigerii, ani w Indonezji. Jest to zatem propozycja normatywna mogąca wpłynąć na rozwój modelu centrypetalnego i zwiększenie prawdopodobieństwa realizacji jego celów.

Jak wskazuje zwłaszcza doświadczenie Nigerii, centrypetalizm tworzy bardzo silne bodźce dla międzyetnicznej współpracy, gdyż zachęca do zawierania i utrzymywania współpracy opartej na innych podstawach niż etniczność. Może nadto przenosić konflikty z poziomu międzyetnicznego na poziom wewnątrzetniczny (Horowitz, 1985, s. 612-613).

\section{Zakończenie}

Istnieją dwa znaczenia pojęcia power-sharing, szerokie i wąskie. Wąskie, skonceptualizowane pojęcie odnosi się do społeczeństw pluralnych, w tym wieloetnicznych. Wyróżnia się cztery podstawowe modele power-sharing w tym rozumieniu. Dwa z nich, libański konfesjonalizm i model Lewisa, mają charakter pierwowzorów power-sharing dla społeczeństw wieloetnicznych. Libański konfesjonalizm jest modelem empirycznym, który głównie skupia się na przeciwdziałaniu problemom związanym z istnieniem podziałów religijnych i wyznaniowych, które po części mają też wymiar etniczny. Z kolei model Lewisa, wprost ukierunkowany na potrzeby społeczeństw wieloetnicznych, ma charakter czysto teoretyczny. Dwa najważniejsze z funkcjonujących obecnie modeli power-sharing to konsocjonalizm oraz centrypetalizm. Pełny konsocjonalizm w wersji lijphartowskiej jest propozycją modelu idealnego, choć opartą na doświadczeniu. W praktyce w różnych społeczeństwach wieloetnicznych i innych pluralnych nie są równocześnie stosowane wszystkie jego rozwiązania albo też wdrożone zostały rozmaite ich warianty odbiegające od propozycji modelowych. Centrypetalizm ma z kolei charakter głównie empiryczny. W piśmiennictwie zostały zidentyfikowane jego podstawowe, stałe $i$ jednolite elementy.

Trzy wzorce power-sharing: konfesjonalizm, model Lewisa i konsocjonalizm opierają się na tym samym fundamencie ideologicznym - prymordializmie. Jak przypomina Lijphart (1995, s. 855) stanowisko to zakłada, że tożsamość etniczna ,jest właściwością dziedziczoną i, nawet jeśli nie stałą, to co najmniej bardzo trudną do zmiany". 
Z perspektywy prymordialistycznej, pomysł stworzenia ponadetnicznych społeczeństw w warunkach wieloetniczności wydaje się nieprawdopodobny do urzeczywistnienia. Ideologiczne założenia centrypetalizmu są odmienne, gdyż mają podstawy konstruktywistyczne. Zwolennicy konstruktywizmu, choć zgadzają się z prymordialistycznym poglądem o tym, że etniczność jest czymś zawczasu ustalonym, to zarazem uważaja, że można ją dalej kształtować dla osiągnięcia jakiegoś pożądanego celu, np. efektywniejszego ograniczania konfliktów niż ma to miejsce w przypadku konfesjonalizmu czy konsocjonalizmu.

Logika konfesjonalizmu, modelu Lewisa i konsocjonalizmu opiera się na założeniu, że w sytuacji, gdy społeczeństwo jakiegoś państwa jest silnie podzielone pod względem etnicznym/narodowym i/lub religijnym/wyznaniowym, jego poszczególne segmenty powinny posiadać odrębną (np. w postaci partii politycznych, choćby tzw. partii etnicznych) reprezentację we władzy państwowej i w ten sposób wpływać na treść podejmowanych decyzji. Taki stan rzeczy może mieć stabilizujący efekt dla sytuacji politycznej, zwłaszcza dzięki ograniczaniu międzysegmentowych konfliktów, w tym etnicznych, religijnych i tzw. communal conflicts. Zarazem jednak ugruntowuje on istniejące międzysegmentowe podziały głównie dlatego, że wzmacnia prawa grupowe.

Logika rządząca centrypetalizmem jest odmienna, gdyż zakłada możliwość integracji politycznej elit grupowych, stymulując je do pojednania i współpracy w poprzek podziałów segmentowych (np. w ramach partii ponadetnicznych). Centrypetalizm, tak jak i pozostałe rodzaje power-sharing, ma za zadanie ułatwianie osiagania stabilności politycznej w społeczeństwach pluralnych, ale jednocześnie powinien osłabiać istniejące podziały międzysegmentowe a nie wzmacniać je, czemu obok rozwiązań formalnych służy promowanie etnicznie neutralnych praktyk prawnych dotyczących statusu jednostek i grup. Dzięki tym cechom centrypetalny model power-sharing określany jest często mianem integracyjnego (integrative power-sharing, Sisk, 1996, s. 5).

Choć celem tego artykułu nie była ocena efektywności stosowania któregokolwiek z omówionych modeli w praktyce, a jedynie ich objaśnienie w zarysie oraz wytłumaczenie istoty power-sharing, warto na koniec zauważyć, że najważniejsze jego wzorce, konsocjonalizm i centrypetalizm, nie rozwiązują wszystkich problemów wspólnej egzystencji odmiennych segmentów w ramach społeczeństw pluralnych, w tym wieloetnicznych. Przeciwnie, posiadają różne wady i mankamenty. I tak konsocjonalizm jest krytykowany zwłaszcza za: ugruntowywanie międzysegmentowych podziałów, spowalnianie procesu decyzyjnego (zwłaszcza w warunkach tzw. wielkiej koalicji), a także mnożenie stanowisk $\mathrm{w}$ administracji różnych szczebli, co może być następstwem stosowania zasady proporcjonalności przy mianowaniu pracowników służby cywilnej oraz wprowadzania autonomii terytorialnej. Z kolei centrypetalizm, choć oceniany pozytywnie w wymiarze rozładowywania napięć w stosunkach między grupami etnicznymi, zdaje się nie zmniejszać konfliktów religijnych między muzułmanami i chrześcijanami, zarówno w Nigerii, jak i w Indonezji, a zatem jego działanie stabilizujące jest ograniczone. Warto jednak pamiętać, że bez istnienia założeń i rozwiązań power-sharing rzeczywistość polityczna i społeczno-ekonomiczna społeczeństw pluralnych, w których są one stosowane, mogłaby być znacznie bardziej skomplikowana, a ograniczanie konfliktów mniej efektywne. 


\section{Bibliografia}

Berman E. (2009), Radical, Religious, and Violent: The New Economics of Terrorism, The MIT Press, Cambridge MA.

Collins English Dictionary, http://www.collinsdictionary.com/dictionary/english/power-sharing, 20.04.2016.

Della Porta D. (2013), Can Democracy Be Saved? Participation, Deliberation and Social Movements, Polity Press, Cambridge.

DeWitt M. R. (2000), Beyond Equilibrium Theory: Theories of Social Action and Social Change Applied to a Study of Power Sharing in Transition, University Press of America, Lanham MD.

Elazar D. J. (1995), Federalism, w: The Encyclopedia of Democracy, vol. 2, red. S. M. Lipset, Routledge, London.

Harb I. (2006), Lebanon's Confessionalism: Problems and Prospects, United States Institute of Peace, http://www.usip.org/publications/lebanons-confessionalism-problems-and-prospects, 21.04.2016.

Horowitz D. L. (1985), Ethnic Groups in Conflict, University of California Press, Berkeley CA.

Horowitz D. L. (2003), Electoral Systems and Their Goals: A Primer for Decision-Makers, „Journal of Democracy", vol. 14, $\mathrm{nr} 4$.

Horowitz D. L. (2014), Ethnic Power Sharing: Three Big Problems, „Journal of Democracy”, vol. 25, $\mathrm{nr} 2$.

Keating E. (1998), Power Sharing: Language, Rank, Gender, and Social Space in Pohnpei, Micronesia, Oxford University Press, Oxford.

Kittilson M. C., Schwindt-Bayer L. (2010), Engaging Citizens: The Role of Power-Sharing Institutions, „The Journal of Politics”, vol. 72, $\mathrm{nr} 4$.

Lewis W. A. (1965a), Beyond African Dictatorship: The Crisis of the One-Party State, „Encounter”, vol. $25, \mathrm{nr} 2$.

Lewis W. A. (1965b), Politics in West Africa, George Allen \& Unwin, London; Oxford University Press, New York.

Lijphart A. (1968), The Politics of Accommodation: Pluralism and Democracy in the Netherlands, University of California Press, Berkeley CA.

Lijphart A. (1980), Democracy in Plural Societies: A Comparative Exploration, Yale University Press, New Haven CT.

Lijphart A. (1995), Multiethnic Democracy, w: The Encyclopedia of Democracy, vol. 3, red. S. M. Lipset, Routledge, London.

Lijphart A. (2008), Thinking about Democracy: Power Sharing and Majority Rule in Theory and Practice, Routledge, London.

Macmillan Dictionary, http://www.macmillandictionary.com/dictionary/british/power-sharing, 20.04.2016.

The New Oxford Dictionary of English (2001), red. J. Pearsall, Oxford University Press, Oxford.

Noel S. (2005), Introduction, w: From Power Sharing to Democracy: Post-conflict Institutions in Ethnically Divided Societies, red. idem, McGill-Queen's University Press, Montreal.

O'Leary B. (2005), Debating Consociational Politics: Normative and Explanatory Arguments, w: From Power Sharing to Democracy: Post-conflict Institutions in Ethnically Divided Societies, red. idem, McGill-Queen's University Press, Montreal.

Parry G. (1995), Types of Democracy, w: The Encyclopedia of Democracy, vol. 4, red. S. M. Lipset, Routledge, London.

Reilly B. (2011), Centripetalism, w: Routledge Handbook of Ethnic Conflict, red. K. Cordell, S. Wolff, Routledge, London. 
Rustad S. A. (2008), Power-sharing and Conflict in Nigeria: Power-sharing Agreements, Negotiations and Peace Processes, „CSCW Papers”, Center for the Study of Civil War, International Peace Research Institute in Oslo, http://file.prio.no/Publication_files/Prio/Rustad\%20 $\% 282008 \% 29 \% 20$ Power-sharing $\% 20$ and $\% 20$ Conflict $\% 20$ in $\% 20$ Nigeria $\% 20 \% 28 \mathrm{CSCW} \% 20$ Paper\%29.pdf, 8.05.2016.

Saurugger S. (2016), Consociationalism, w: Encyclopaedia Britannica, http://www.britannica.com/ topic/consociationalism, 25.04.2016.

Sir Arthur Lewis - Biographical (2014), Nobelprize.org, Nobel Media AB, http://www.nobelprize.org/ nobel_prizes/economics/laureates/1979/lewis-autobio.html, 20.04.2016.

Sisk T. D. (1996), Power Sharing and International Mediation in Ethnic Conflicts, Carnegie Commission on Preventing Deadly Conflicts, United States Institute of Peace, Washington DC.

Stownik Politologii (2008), thum. M. Kornobis, P. Kornobis, K. Wolański, Wydawnictwo Naukowe PWN, Warszawa.

Trzciński K. (2013), Demokratyzacja w Afryce Subsaharyjskiej. Perspektywa zachodnioafrykańskiej myśli politycznej, Oficyna Wydawnicza ASPRA-JR, Warszawa.

Trzciński K. (2015), Centrypetalizm - integrujacy system polityczny dla państw wieloetnicznych. Zarys teorii empirycznej, „Studia Polityczne”, t. 39, nr 3.

Wilford R. (2003), Power-sharing, w: The Concise Oxford Dictionary of Politics, red. I. McLean, A. McMillan, Oxford University Press, Oxford.

Wolff S. (2010), Consociationalism, Power Sharing, and Politics at the Center, w: The International Studies Encyclopedia, vol. 2, red. R. A. Denemark, Wiley-Blackwell, Malden MA.

Zdeb A. (2014), Odbudowa dysfunkcyjnych państw podzielonych. O aktualności konsocjonalizmu, w: Państwa dysfunkcyjne i międzynarodowe wysitki zmierzajace do ich naprawy, red. R. Kłosowicz, Wydawnictwo Uniwersytetu Jagiellońskiego, Kraków.

\section{The essence and key models of power-sharing in a multi-ethnic context. An outline of issues}

\section{Summary}

This paper discusses the essence and key models of power-sharing. While power-sharing can be construed in a very broad way, a narrow understanding of it is analyzed in this paper. It refers to the phenomenon of the sharing of state power by different segments (e.g. ethnic groups and/or religious communities) of plural societies, especially multi-ethnic and/or multi-religious groups. There are two aims of this paper: 1) to explain how the concept of power-sharing in a multi-ethnic context is understood in the literature, and 2) to identify the main characteristics of the principal models of power-sharing (confessionalism, the Lewis Model, consociationalism, and centripetalism).

Key words: power-sharing, confessionalism, Lewis Model, consociationalism, centripetalism 
